\title{
Typology and Perception of Informal Green Space in Urban Interstices:
}

A case study of Ichikawa City, Japan

\author{
Minseo Kim ${ }^{1 *}$, Christoph D.D. Rupprecht ${ }^{2}$ and Katsunori Furuya ${ }^{3}$ \\ 1 Graduate School of Horticulture, Chiba University \\ 2 FEAST Project, Research Institute for Humanity and Nature \\ 3 Graduate School and Faculty of Horticulture, Chiba University \\ * Corresponding Author, Email: hellominseo@gmail.com
}

Received: Aug 4, 2017; Accepted: January 13, 2019

Key words: informal green space, urban interstices, urban green space, supplementary green space, vacant land

\begin{abstract}
Multitudinous studies about urban green space (UGS) reveal that designed and managed UGS may provide not only social, environmental, and economic benefits for cities, but also mental, physical, and physiological benefits for their residents. However, past studies have focused on widely recognized green spaces in urban areas such as parks, gardens, and forests. Wasteland, wilderness, and unplanned in-between margins, which have been called informal green space (IGS), could provide supplementary green space. This study explores IGS in Ichikawa City, a post-industrial satellite town of Tokyo with scarce UGS, by addressing the following questions: (a) What types of non-standardized and unsystematised green space exist in the target area? (b) How is IGS in the target area perceived? (c) Could IGS be considered supplementary green space for the city? Using a systematic land use survey, we identified nine types of IGS in Ichikawa City that accounted for $6.35 \%$ of total land use. A questionnaire survey showed that undergraduate students recognize the existence of IGS in their neighbourhood, perceive multiple benefits and see especially street verges, unimproved land and water verges as potential supplementary green space. We conclude that IGS can serve as a supplementary green space and discuss how IGS might be integrated into green space planning to improve residents' well-being.
\end{abstract}

\section{INTRODUCTION}

Today, about $54 \%$ of the world's population live in urban areas, and this ratio is expected to increase to about $70 \%$ within 30 years (United Nations, Department of Economic and Social Affairs, Population Division, 2015). As cities grow, either new urban green spaces (UGS) are provided as part of the development of the city or, more often, much of the original green spaces disappear or become fragmented (Barbosa et al., 2007; Mensah, 2014). The role of UGS in this urbanization process has been increasingly emphasized in terms of economic, environmental, and social importance (Wright Wendel, Zarger, \& Mihelcic, 2012).

Many studies have proposed definitions and classification systems for UGS. Definitions of UGS widely accepted may call for a 'natural surface' or 
include 'nature settings', and may also include 'blue space' such as water elements, but definitions of UGS and its classification may differ depending on the context (WHO Regional Office for Europe, 2016). Nevertheless, the literature on UGS emphasizes its contributions not only to the urban ecosystem but also to human well-being. A consensus is emerging regarding the benefits of UGS for the ecosystem, underlining that UGS as a connected network helps to mitigate biodiversity loss and provides ecosystem-services to humans and other living beings as Green Infrastructure (GI) (Benedict \& McMahon, 2002). In addition to biodiversity benefits, UGS can play a vital role in climate change adaptation and mitigation (Cohen-Shacham et al., 2016). Rich research on the relationship between human and nature as mediated by UGS argues that nature within UGS can provide positive impacts on human well-being by providing nature contact opportunities (Bertram \& Rehdanz, 2015). UGS can also increase social cohesion, supporting communal living and identity (Martin, Warren, \& Kinzig, 2004).

Not all UGS, however, is created intentionally. In the modern urban structure, the extensive complexities of urbanization and the proliferation of development plans from multiple agencies involved in urban planning make it difficult to clearly distinguish the spatial and social contexts of the city (Speer, 2015). Therefore, urban interstitial spaces exist that may be associated with leftover spaces or by-products emerging from heterogeneous and discrete urban planning (Edensor, 2005). The interstice is a 'small or narrow space' and it may exist among all types of urban contexts. These interstitial spaces can have an important function not only as habitats but also for the relationship between nature and humans (Shoard, 2000; Edensor, 2005). Urban interstitial spaces may be referred to as 'margins', 'fringe', and 'in-between' from the viewpoint of space formation. In other words, these spaces are surrounded by other spaces which are more standardized, regulated through legal power or imbued with strong identity (Speer, 2015).

In recent research, there is a growing interest in ruderal landscapes (Del Tredici, 2010) with spontaneous vegetation in urban interstices. These are often referred to as 'urban wilderness' or 'wasteland' with a new perspective on urban ecology and residents' recreation. They comprise various successional stages of vegetation and ecological communities with often high species richness. Yet despite their high potential, wastelands in urban areas are still often seen as abandoned lands, where spontaneous vegetation grows without human maintenance (Muratet et al., 2007). Examining such informal green space (Rupprecht, Christoph D D \& Byrne, 2014a; Rupprecht, Christoph D D et al., 2015), from vacant lots and riverbanks to railway or street verges, can elicit many valuable new questions and insights, as this area has received only limited attention from researchers and local governments. Informal green space (IGS) may support functions of formal green space that are generally expected from UGS such as parks, gardens, and city forests, but the informal nature of IGS may also place it in a precarious position vulnerable to politics, system interventions, and aesthetic preferences at the same time (Rupprecht, Christoph D D et al., 2015).

In this exploratory study, we investigate the availability of such ambivalent urban spaces, examining IGS occurrence and its perception in Ichikawa City, a satellite town of Tokyo with scarce formal UGS and thus a need for supplementary green space. The study aims to do this by addressing the following questions: (a) What types of non-standardized and unsystematised green space exist in the target area? (b) How is IGS in the 
target area perceived? (c) Could IGS be considered supplementary green space for the city?

\section{METHOD}

\subsection{Study Location}

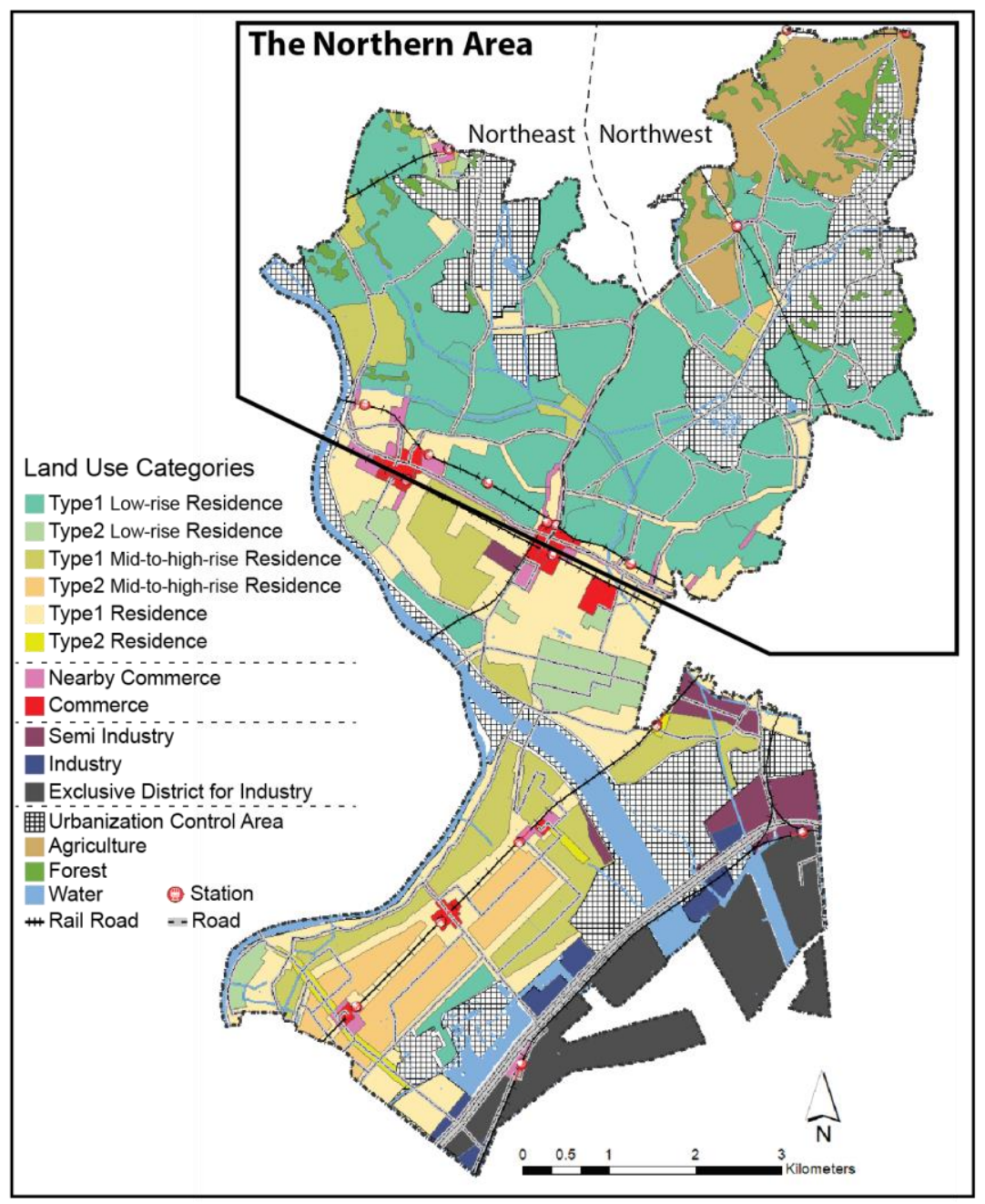

Figure 1. Study site

We focused on Ichikawa City (Chiba Prefecture, Japan) as the study area, as the city has faced issues balancing green space provision with development since a period of rapidly developing urbanization. The city has been growing since about 1955 in parallel with Japan's high economic growth phase, centred on Tokyo. From this period, most of the previously existing farmland was converted to residential land use. Currently, more than half of the area is urbanized, including residential, commercial, and industrial land use (Ichikawa City Urban Planning Division, 2004, 2013). The city was formed as a satellite town of Tokyo under the metropolis' strong influence. The effects can be seen in the fragmentation of existing local forests, and in the low community cohesion resulting from a resident composition mainly shaped by in-migration (Ichikawa City Urban Planning Division, 2017). The municipal government has divided the entire city into 
four parts for planning purposes: Northeast, Northwest, Central, and South (Ichikawa City Urban Planning Division, 2004). We studied the Northern part of the city including both Northeast and Northwest (Figure 1). The entire city area covers $56.39 \mathrm{~km}^{2}$, of which the North area covers $29.68 \mathrm{~km}^{2}$ (52.63\% of the whole area), and about 480,570 population live in the city, of which the study site composes a population of 196,160 (40.81\% of the whole population).

The city provides $3.45 \mathrm{~km}^{2}$ of urban parks, $2.27 \mathrm{~km}^{2}$ of public facility green spaces (children' parks, citizen farms, schools, sport facilities, and roadside trees) and $1.21 \mathrm{~km}^{2}$ of private facility green spaces (temple forests, citizen forests, etc). The per capita urban park area of Ichikawa is $3.15 \mathrm{~m}^{2}$. Even if all green facilities are included, the green space area per person is only $7.28 \mathrm{~m}^{2}$ (Ichikawa City Urban Planning Division, 2004). This, however, is not sufficient under the Urban Park Act of Japan, which stipulates $10 \mathrm{~m}^{2}$ per capita urban park area as the minimum. This leaves Ichikawa City in the position of having to supply additional green space and was the reason we chose it as the target of our study. The city as a whole has various land use patterns: $56 \%$ residential districts, $3 \%$ commercial districts, $10 \%$ industrial districts, and $34 \%$ urbanization control areas with agricultural districts and forest. The Northern area includes all agricultural districts, forests, and most of the urbanization control areas, but no industrial districts.

\subsection{Survey Research Design}

\subsubsection{Field Work Survey}

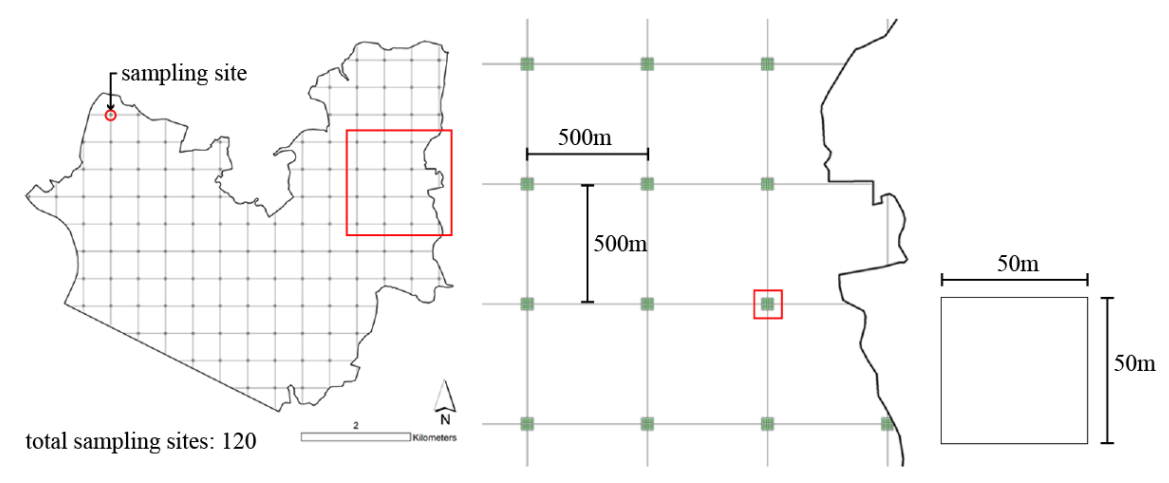

Figure 2. Land use survey design and sampling strategy

To measure the distribution and proportion of IGS in Ichikawa, we used a systematic sampling strategy (Hirzel \& Guisan, 2002; Rupprecht, Christoph D D \& Byrne, 2014a). Hirzel and Guisan (2002) lay out four types of sampling strategies: 'Equal-stratified,' 'Regular,' 'Random,' and 'Proportional-stratified'. They argue that 'Regular' and 'Equal-stratified' are more effective methods to measure presence and absence prediction. We used a regular sampling strategy that is appropriate when there is no environmental information about the study site before fieldwork. We used this regular sampling strategy as we needed to quantify distribution and proportion of not only UGS but also IGS in the study site, but due to its informal nature, no information regarding IGS was available in advance. For this purpose, we set a $500 \mathrm{~m}$ grid and located $50 \mathrm{~m}$ square sample sites on the 
intersections (Figure 2). The number of sample sites on the study site was 120 and the area was $0.3 \mathrm{~km}^{2}$, which accounts for $1.01 \%$ of the study site area (total North area: $29.68 \mathrm{~km}^{2}$ ). Sample sites were given identification numbers from 1 to 120 , and were visited and surveyed for land use area, form, and vegetation structure. Data was recorded on fieldwork sheets and subsequently entered into a GIS to calculate area and distribution. In principle, assessment was conducted on the ground at the study site location to identify UGS and IGS, but we used Google Earth where it was difficult to access the site. The minimum area of all elements recorded was set at $1 \mathrm{~m}^{2}$. Microsoft Excel 2016 and IBM SPSS 25 were used for statistical analyses, and ArcGIS (version 10.3.1) for mapping field work results.

\subsubsection{Questionnaire Survey}

To identify whether IGS can be perceived as a type of urban green space we conducted a questionnaire survey among students of landscape architecture and agricultural science. This questionnaire served as a first exploratory step in a larger research plan, with the aim to initially study the perception of students who have an interest in urban green space and understand that green space plays a role in the urban area. The questionnaire included 91 questions in three categories: Respondents' Characteristics, General Perception of Urban Nature and Urban Green Space, and Perception of IGS.

\section{RESULT}

\subsection{Distribution of UGS}

We classified 19 types of UGS based on the Ichikawa Green Master Plan (2004) and our field work in the sample sites. Three sites were inaccessible (sites 18 and 104 were in the middle of construction sites, site 38 was in the middle of the Edo river). Sites 34 and 104 had not only no UGS but also no IGS because they were located at the centre of the railway, surrounded by buildings and paved roads. The proportion of UGS among all sample sites was $37.21 \%\left(0.11 \mathrm{~km}^{2}\right)$ (Table 1$)$. Among all UGSs in the sample sites, 'orchard' was the most abundant at $28.67 \%\left(0.032 \mathrm{~km}^{2}\right)$, followed by 'garden' (17.38\%), 'arable land' (14.86\%), and 'school' (13.70\%) as types contributing more than $10 \%$. The number of 'garden' spaces was the highest among all UGSs (349). While 'Green space of a housing complex' accounts for under $1 \%$ among all sample sites; we found 57 discrete spaces.

Table 1. UGSs in Ichikawa

\begin{tabular}{lrrrr}
\hline Typology & $\begin{array}{r}\text { Area } \\
\left(\mathrm{m}^{2}\right)^{1}\end{array}$ & $\begin{array}{r}\text { Count }^{2} \\
\text { \% total } \\
\text { area }^{3}\end{array}$ & $\begin{array}{r}\% \text { of } \\
\text { UGS }^{4}\end{array}$ \\
\hline Arable land & $16,577.00$ & 32 & 5.52 & 14.86 \\
Camping zone & $2,391.65$ & 1 & 0.80 & 2.14 \\
Cemetery & $4,021.03$ & 5 & 1.34 & 3.60 \\
Commercial green space & 169.75 & 7 & 0.06 & 0.15 \\
Community garden & $1,192.24$ & 2 & 0.40 & 1.07 \\
Company green space & 6.43 & 1 & 0.00 & 0.01 \\
Local forest & $4,956.99$ & 11 & 1.65 & 4.44 \\
Garden & $19,396.28$ & 349 & 6.47 & 17.38 \\
Hedge & 136.86 & 11 & 0.05 & 0.12 \\
\hline
\end{tabular}




\begin{tabular}{lrrrr}
\hline Typology & $\begin{array}{r}\text { Area } \\
\left(\mathrm{m}^{2}\right)^{1}\end{array}$ & $\begin{array}{r}\text { Count }^{2} \\
\begin{array}{r}\text { \% total } \\
\text { area }^{3}\end{array}\end{array}$ & $\begin{array}{r}\% \text { of } \\
\text { UGS }^{4}\end{array}$ \\
\hline Institutional green space & $4,029.21$ & 11 & 1.34 & 3.61 \\
Green space of a housing complex & $2,366.24$ & 57 & 0.79 & 2.12 \\
Nursery & 242.21 & 1 & 0.08 & 0.22 \\
Orchard & $31,997.70$ & 27 & 10.67 & 28.67 \\
Park & $3,662.52$ & 12 & 1.22 & 3.28 \\
School & $15,287.29$ & 9 & 5.10 & 13.70 \\
Slope & 563.30 & 5 & 0.19 & 0.50 \\
Sports facility & 523.93 & 2 & 0.17 & 0.47 \\
Street tree & 9.14 & 1 & 0.00 & 0.01 \\
Temple & $4,077.19$ & 6 & 1.36 & 3.65 \\
\hline Total & $111,606.96$ & 550 & 37.21 & 100.00 \\
\hline
\end{tabular}

${ }^{1}$ Amount of the relevant UGS area across all sample sites. ${ }^{2}$ Number of UGS found across all sample sites. ${ }^{3}$ Percentage of UGS across all sample sites. ${ }^{4}$ Percentage of the relevant type of UGS among the total UGS found.

\subsection{Distribution of IGS}

We categorized IGSs into nine types based on previous research and revisions made as a result of our field work (Table 2 and Figure 3). Spaces less than $1 \mathrm{~m}^{2}$ were excluded.

Table 2. Typology of Informal Green Space in Ichikawa (IGS typology by Rupprecht, Christoph D D and Byrne (2014b) with revisions and added types.)

\begin{tabular}{|c|c|}
\hline IGS & Description (non-exclusive criteria) \\
\hline Vacant lots & $\begin{array}{l}\text { Form } \\
\text { - Uninhabited. } \\
\text { - Some of the housing structures in the site are abandoned or empty. } \\
\text { - The space within the boundaries of the land block is empty. } \\
\text { Vegetation } \\
\text { - Grass cover throughout the site. } \\
\text { - Management of vegetation is irregular, minimal or neglected. } \\
\text { - Irregular or minimal management of vegetation to cut off overgrown plants. } \\
\text { - Composition of the vegetation structure mostly consists of herbaceous plants. } \\
\text { Access } \\
\text { - There are either blocking structures such as a fence or dividing structures such } \\
\text { - There may be a signboard to prohibit access or unwanted behaviour. } \\
\text { - No fences, no signboards. }\end{array}$ \\
\hline $\begin{array}{c}\text { Street } \\
\text { verges }\end{array}$ & $\begin{array}{l}\text { Form } \\
\text { - Adjacent to roads. } \\
\text { - In in-between broad cracks in the pavement of sidewalks. } \\
\text { - Boundaries between the paved and the unpaved may not be clear. } \\
\text { Vegetation } \\
\text { - Composition of the vegetation structure mostly consists of herbaceous plants. } \\
\text { - Herbaceous plant communities are above a shallow base of the old pavement } \\
\text { and mainly form the linear structure along the edge of the roads. } \\
\text { - Communities of vegetation mainly form a linear structure along the edge of } \\
\text { roads. } \\
\text { - In case of relatively low human disturbance, vegetation communities stretch } \\
\text { - Manto an atypical shape. } \\
\text { - Irregular or minimal management of vegetation to cut off overgrown plants. } \\
\text { Access } \\
\text { - There is no blocking structure such as a fence. }\end{array}$ \\
\hline $\begin{array}{c}\text { Water } \\
\text { verges }\end{array}$ & $\begin{array}{l}\text { Form } \\
\text { - Adjacent to rivers, irrigation canals, streams, and wells, where both water and } \\
\quad \text { vegetation exists. } \\
\text { - In the cracks on paved embankments. } \\
\text { Vegetation } \\
\text { - Most are covered with herbaceous plants, but occasionally there are shrubs or } \\
\quad \text { trees. } \\
\text { - Plants are around water or in contact with water. } \\
\text { Access }\end{array}$ \\
\hline
\end{tabular}




\begin{tabular}{|c|c|}
\hline IGS & $\begin{array}{l}\text { Description (non-exclusive criteria) } \\
\text { - There is a closed fence or tall wall with an entry-prohibited signboard. } \\
\text { - A high embankment surrounds the site to restrict access. } \\
\text { - There are no blocking structures including sign, fence, or bank. }\end{array}$ \\
\hline Gaps & $\begin{array}{l}\text { Form } \\
\text { - Between buildings, walls, structures, and fences. } \\
\text { - The smaller the space, the more likely it is to be left over and neglected. } \\
\text { Vegetation } \\
\text { - Composition of the vegetation structure mostly consists of herbaceous plants. } \\
\text { - Management of vegetation is irregular, minimal or neglected. } \\
\text { - Irregular or minimal management of vegetation to cut off overgrown plants. } \\
\text { Access } \\
\text { - It may be inconvenient to pass because it is not wide enough. } \\
\text { - One side may be blocked with structures, but the other side may be open. }\end{array}$ \\
\hline Brownfields & $\begin{array}{l}\text { Form } \\
\text { - Former use of industrial or commercial purposes but now unused. } \\
\text { - Site boundaries include the building's area and near an entrance area. } \\
\text { Vegetation } \\
\text { - Vegetation grows spontaneously above the abandoned and unmanaged soil } \\
\text { and debris. } \\
\text { - Management of vegetation is irregular, minimal or neglected. } \\
\text { - Irregular or minimal management of vegetation to cut off overgrown plants. } \\
\text { Access } \\
\text { - There is a closed fence or tall wall with a prohibited signboard. }\end{array}$ \\
\hline $\begin{array}{l}\text { Unimproved } \\
\text { lands }\end{array}$ & $\begin{array}{l}\text { Form } \\
\text { - Development may proceed. } \\
\text { - No service infrastructure such as telephone, electricity, water pipe, or a road } \\
\quad \text { for direct access without structural boundaries. } \\
\text { Vegetation } \\
\text { - Most are covered with herbaceous plants, but occasionally there are shrubs or } \\
\text { trees. } \\
\text { - The vegetation is dense, or minimal management is carried out to prevent } \\
\text { crime. } \\
\text { Access } \\
\text { - There is a closed fence or tall wall with an entry-prohibited signboard or no } \\
\text { obstacle to entering the space. }\end{array}$ \\
\hline $\begin{array}{l}\text { Parking lot } \\
\text { verges }\end{array}$ & $\begin{array}{l}\text { Form } \\
\text { - Sites used for parking purposes. } \\
\text { - Sites that utilize vacant lots or unimproved lands for parking purposes rather } \\
\text { than a professional parking lot built by a management company. } \\
\text { Vegetation } \\
\text { - Composition of the vegetation structure mostly consists of herbaceous plants. } \\
\text { - Mainly herbaceous plants are concentrated on the edge above the cracked } \\
\text { pavement of the site except for parking areas. } \\
\text { Access } \\
\text { - There is no obstacle to entering the space. } \\
\text { - Some sites are enclosed by fences or a low wall, but the entrance is mostly } \\
\text { open. }\end{array}$ \\
\hline $\begin{array}{l}\text { Railroad } \\
\text { verges }\end{array}$ & $\begin{array}{l}\text { Form } \\
\text { - Sites where plants are distributed along the railway. } \\
\text { - Site boundaries include parts adjacent to tracks and slopes. } \\
\text { Vegetation } \\
\text { - Composition of the vegetation structure mostly consists of herbaceous plants. } \\
\text { - Management of vegetation is irregular, minimal or neglected, however, if it is } \\
\text { determined to be a safety hazard, it will be removed. } \\
\text { Access } \\
\text { - Public access and use mostly restricted to prevent accidents. }\end{array}$ \\
\hline $\begin{array}{c}\text { Overgrown } \\
\text { structures }\end{array}$ & $\begin{array}{l}\text { Form } \\
\text { - Plants cover artificial structures: walls, fences, bridges, and signboards etc. } \\
\text { Vegetation } \\
\text { - Vegetation composition consists of plants that have the characteristics of } \\
\quad \text { enclosing structures. } \\
\text { - Vegetation grows vertically, relying on the structures. } \\
\text { - Management of vegetation is irregular or minimal to maintain structural } \\
\quad \text { integrity. } \\
\text { Access } \\
\text { - No block structures. } \\
\text { - Removed and not accessible directly. (i.e. plants on the wall of a tall building) }\end{array}$ \\
\hline
\end{tabular}




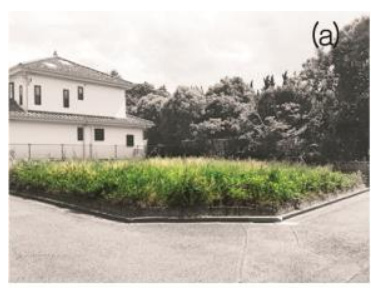

(d)
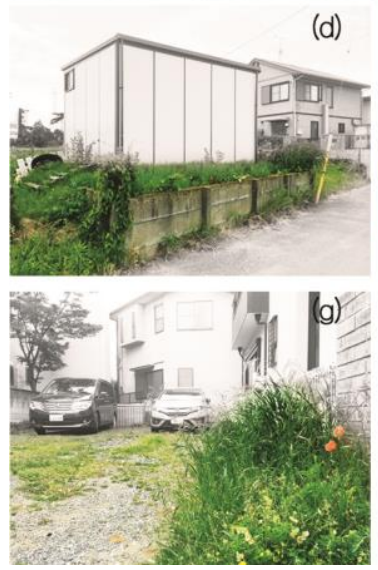

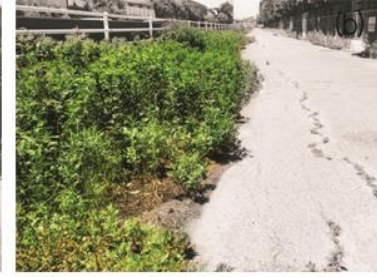

(e)
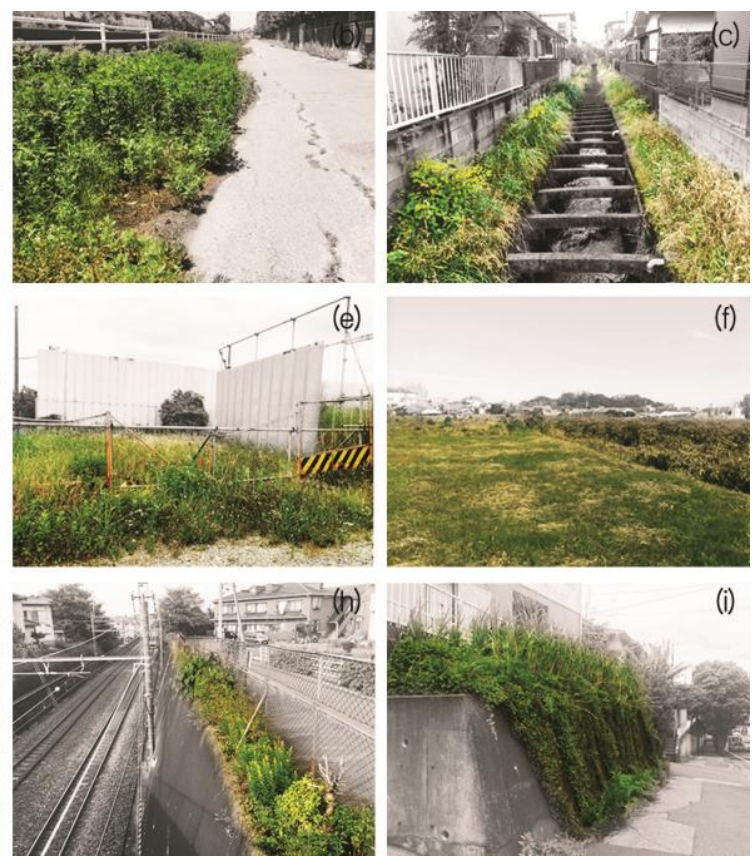

Figure 3. Nine types of IGSs

(a) vacant lots; (b) street verges; (c) water verges: (d) gaps; (e) brownfields; (f) unimproved lands; (g) parking lot verges; (h) railroad verges; (i) overgrown structures

The proportion of IGS we found in the sample sites was $6.36 \%$ $\left(20,694.11 \mathrm{~m}^{2}\right)$ and the number of them in the sites is 170 (Table 3). The type accounting for the largest area in the sample sites was 'Unimproved land' $\left(7,722.10 \mathrm{~m}^{2}, 2.57 \%\right.$ of total surveyed area) which comprised $40.47 \%$ of the total IGS area found in the sample sites. Among the proportion of whole IGSs found in the sites, 'Vacant lots' $\left(3,702.83 \mathrm{~m}^{2}, 19.41 \%\right)$, 'Gap' $\left(12.40 \%, 2,366.52 \mathrm{~m}^{2}\right)$, and 'Water verges' $\left(10.26 \%, 1,956.76 \mathrm{~m}^{2}\right)$ contributed more than 10\%. 'Unimproved lands' showed the highest proportion of the area, but 'Gap' constituted the largest number of IGSs found. Among the 170 IGSs, 'Gap' accounts for 50, over 20 spaces were found for 'Vacant lots' (31), 'Streets verges' (28), and 'Parking lot verges' (23). 'Brownfields', 'Railroad verges', and 'Overgrown structures' showed a lower number of sites and were rarer.

Table 3. IGSs in Ichikawa

\begin{tabular}{lcrrr}
\hline \multicolumn{1}{c}{ Typology } & Area $\left(\mathrm{m}^{2}\right)^{1}$ & Count $^{2}$ & $\%$ total area $^{3}$ & $\%$ of IGS \\
\hline Vacant lots & $3,702.83$ & 32 & 1.23 & 19.41 \\
Street verges & $1,154.55$ & 28 & 0.38 & 6.05 \\
Water verges & $1,956.76$ & 9 & 0.65 & 10.26 \\
Gaps & $2,366.52$ & 51 & 0.79 & 12.40 \\
Brownfields & 978.63 & 2 & 0.33 & 5.13 \\
Unimproved lands & $7,722.10$ & 19 & 2.57 & 40.47 \\
Parking lot verges & $1,085.69$ & 23 & 0.36 & 5.69 \\
Railroad verges & 97.28 & 2 & 0.03 & 0.50 \\
Overgrown structures & 16.45 & 4 & 0.01 & 0.09 \\
\hline Total & $19,080.81$ & 170 & 6.35 & 100.00 \\
\hline${ }^{1}$ Amount of area represented by the relevant type of IGS in the sample sites. ${ }^{2}$ Number of the \\
sample sites where IGS was found. ${ }^{3}$ Percentage of IGS in all sample sites. ${ }^{4}$ Percentage of the \\
relevant type of IGS among the total IGS found.
\end{tabular}

We were able to identify IGS on 70 sites of the total 120 sample sites surveyed and analysed IGS distribution according to land use patterns (Figure 4 and Table 4). The proportion of the identified IGS on each sample site ranged from $0.04 \%$ to $99.89 \%$ and 50 sites had less than $10 \%$. Among 
the sites with over $10 \%$ IGS area, 11 of 20 sites were in an urbanization control district, and $68.4 \%$ was comprised of 'Unimproved lands'.

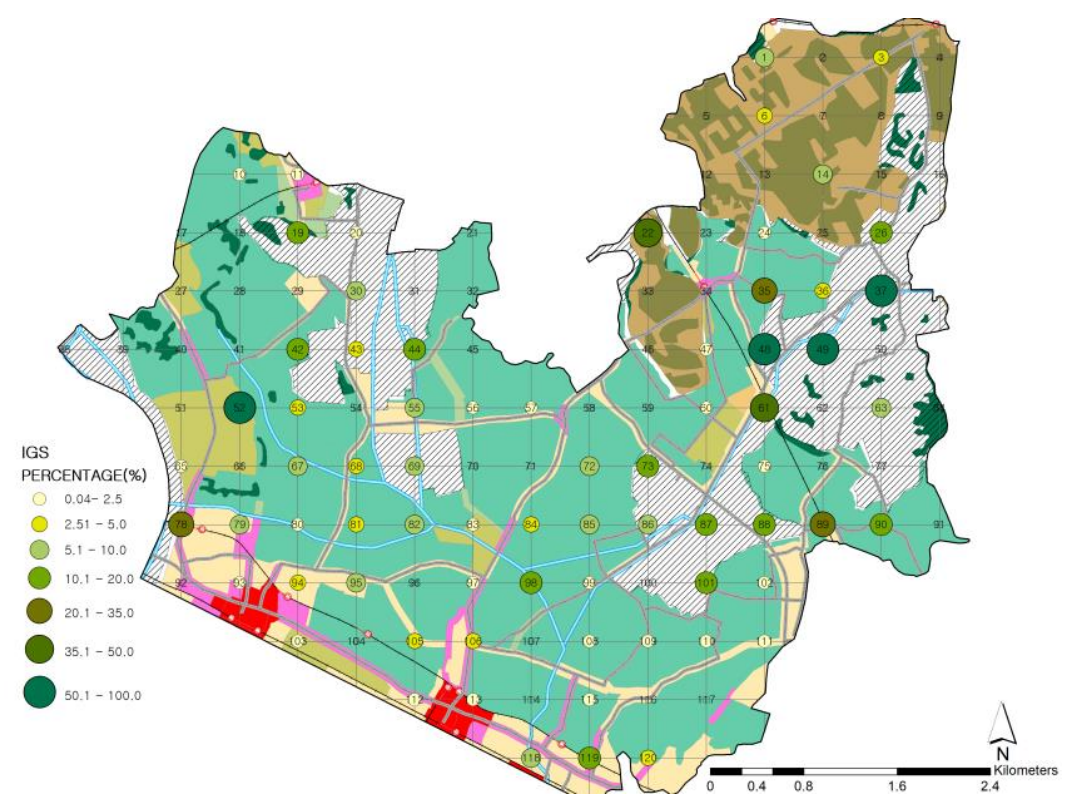

Figure 4. Percentage of IGS area found at each sample site. Numbers inside the sample sites indicate site numbers.

Table 4. Summary Statistics of IGS Distribution on 70 sites

\begin{tabular}{|c|c|c|c|c|c|}
\hline Land use & No. $S^{1}$ & Count $^{2}$ & $\begin{array}{c}\text { Area IGS } \\
\left(\mathrm{m}^{2}\right)^{3}\end{array}$ & $\begin{array}{l}\text { \% IGS in } \\
\text { site }^{4}\end{array}$ & Types of IGS 5 \\
\hline \multirow{5}{*}{$\begin{array}{l}\text { Agriculture } \\
\text { (5) }\end{array}$} & 1 & 2 & 208.22 & 8.32 & $\mathrm{Va}, \mathrm{Ga}$ \\
\hline & 3 & 3 & 102.18 & 4.08 & $\mathrm{Ga}, \mathrm{Pa}(2)$ \\
\hline & 6 & 2 & 97.08 & 3.88 & $\mathrm{Ga}, \mathrm{Pa}$ \\
\hline & 14 & 1 & 195.56 & 7.82 & $\mathrm{Ga}$ \\
\hline & 22 & 3 & $1,110.04$ & 44.40 & Un \\
\hline \multicolumn{2}{|c|}{ subtotal } & 11 & $1,713.08$ & \multicolumn{2}{|c|}{$\begin{array}{c}\text { Va:1, St: 0, Wa: 0, Ga: 4, Pa:3, } \\
\text { Br: 0, Un: 3, Ra:2, Ov:1 }\end{array}$} \\
\hline \multirow{7}{*}{$\begin{array}{c}\text { Commerce } \\
\text { (7) }\end{array}$} & 11 & 1 & 37.43 & 1.50 & $\mathrm{Ga}$ \\
\hline & 78 & 5 & 556.27 & 22.25 & $\mathrm{Wa}, \mathrm{Ga}(3), \mathrm{St}$ \\
\hline & 93 & 1 & 50.93 & 2.03 & $\mathrm{Ov}$ \\
\hline & 106 & 2 & 89.86 & 3.59 & $\mathrm{~Pa}, \mathrm{Ga}$ \\
\hline & 112 & 1 & 48.08 & 1.92 & $\mathrm{Va}$ \\
\hline & 113 & 1 & 53.50 & 2.14 & $\mathrm{Ra}$ \\
\hline & 119 & 6 & 228.42 & 17.93 & $\begin{array}{c}\mathrm{Ra}, \mathrm{Va}(2), \mathrm{St}(2), \\
\mathrm{Pa}\end{array}$ \\
\hline \multicolumn{2}{|c|}{ subtotal } & 17 & $1,064.49$ & \multicolumn{2}{|c|}{$\begin{array}{l}\text { Va: 3, St: 3, Wa: 1, Ga:5, Pa:2, } \\
\text { Br: 0, Un: 0, Ra: 2, Ov:1 }\end{array}$} \\
\hline \multirow{13}{*}{$\begin{array}{l}\text { Residential } \\
\quad(40)\end{array}$} & 10 & 1 & 7.73 & 0.30 & $\mathrm{~Pa}$ \\
\hline & 24 & 1 & 9.95 & 0.39 & $\mathrm{~Pa}$ \\
\hline & 35 & 5 & 620.34 & 24.81 & $\mathrm{Ga}(3), \mathrm{St}, \mathrm{Un}$ \\
\hline & 36 & 2 & 109.26 & 4.37 & $\mathrm{Va}, \mathrm{Un}$ \\
\hline & 42 & 2 & 259.13 & 10.36 & $\mathrm{Va}(2)$ \\
\hline & 47 & 1 & 28.72 & 1.14 & $\mathrm{~Pa}$ \\
\hline & 52 & 8 & $1,252.48$ & 50.09 & $\mathrm{Ga}(3), \mathrm{Br}, \mathrm{St}(4)$ \\
\hline & 53 & 1 & 78.63 & 3.14 & $\mathrm{Va}$ \\
\hline & 55 & 5 & 152.10 & 6.08 & $\mathrm{St}, \mathrm{Wa}(2), \mathrm{Pa}(2)$ \\
\hline & 56 & 1 & 1.00 & 0.04 & $\mathrm{Ga}$ \\
\hline & 57 & 2 & 11.87 & 0.47 & $\mathrm{Ga}, \mathrm{Ov}$ \\
\hline & 60 & 3 & 62.04 & 2.48 & $\mathrm{Ga}, \mathrm{Pa}(2)$ \\
\hline & 65 & 2 & 48.86 & 1.95 & $\mathrm{St}(2)$ \\
\hline
\end{tabular}




\begin{tabular}{|c|c|c|c|c|c|}
\hline Land use & No. $S^{1}$ & Count $^{2}$ & $\begin{array}{c}\text { Area IGS } \\
\left(\mathrm{m}^{2}\right)^{3}\end{array}$ & $\begin{array}{c}\text { \% IGS in } \\
\text { site }^{4}\end{array}$ & Types of IGS ${ }^{5}$ \\
\hline & 67 & 1 & 136.01 & 5.44 & $\mathrm{Va}$ \\
\hline & 68 & 1 & 76.31 & 3.05 & $\mathrm{Ga}$ \\
\hline & 72 & 2 & 245.64 & 9.82 & $\mathrm{Va}, \mathrm{Pa}$ \\
\hline & 75 & 1 & 15.70 & 0.62 & $\mathrm{Va}$ \\
\hline & 79 & 2 & 200.14 & 8.00 & $\mathrm{Va}(2)$ \\
\hline & 80 & 1 & 39.86 & 1.59 & $\mathrm{~Pa}$ \\
\hline & 81 & 3 & 67.35 & 2.69 & $\mathrm{St}, \mathrm{Ga}(2)$ \\
\hline & 82 & 4 & 184.56 & 7.38 & $\mathrm{Va}, \mathrm{Ga}(2), \mathrm{Un}$ \\
\hline & 83 & 1 & 5.61 & 0.22 & $\mathrm{Ga}$ \\
\hline & 84 & 1 & 123.52 & 4.94 & $\mathrm{Va}$ \\
\hline & 85 & 9 & 224.47 & 8.97 & $\begin{array}{c}\text { Va, St, Wa, Ga(5), } \\
\mathrm{Pa}\end{array}$ \\
\hline & 89 & 3 & 729.85 & 29.19 & $\mathrm{Va}, \mathrm{Ga}(2)$ \\
\hline & 90 & 6 & 485.65 & 19.42 & $\mathrm{Va}, \mathrm{Ga}, \mathrm{St}, \mathrm{Pa}(3)$ \\
\hline & 94 & 1 & 79.36 & 3.17 & $\mathrm{St}$ \\
\hline & 95 & 1 & 200 & 8 & $\mathrm{Ga}$ \\
\hline & 97 & 1 & 50.08 & 2.00 & $\mathrm{Va}$ \\
\hline & 98 & 2 & 322.90 & 12.91 & $\mathrm{Wa}(2)$ \\
\hline & 99 & 2 & 45.72 & 1.82 & $\mathrm{Ga}, \mathrm{Pa}$ \\
\hline & 102 & 1 & 15.26 & 0.61 & $\mathrm{~Pa}$ \\
\hline & 103 & 1 & 7.80 & 0.31 & $\mathrm{Ga}$ \\
\hline & 105 & 3 & 76.87 & 3.07 & $\mathrm{St}(2), \mathrm{Ov}$ \\
\hline & 108 & 2 & 50.28 & 2.01 & $\mathrm{Va}, \mathrm{Pa}$ \\
\hline & 109 & 1 & 19.65 & 0.78 & $\mathrm{Ga}$ \\
\hline & 110 & 1 & 4.96 & 0.19 & $\mathrm{Ga}$ \\
\hline & 111 & 3 & 12.08 & 0.76 & $\mathrm{St}(2), \mathrm{Ga}$ \\
\hline & 115 & 1 & 10.04 & 0.40 & St \\
\hline & 118 & 1 & 125.53 & 5.02 & $\mathrm{Va}$ \\
\hline & 120 & 2 & 62.71 & 2.50 & $\mathrm{Va}, \mathrm{Ga}$ \\
\hline \multicolumn{2}{|c|}{ subtotal } & 91 & $6,244.32$ & \multicolumn{2}{|c|}{$\begin{array}{c}\text { Va: 18, St:17, Wa:5, Ga: } 30, \\
\text { Br:1, Un:3, Pa:16, Ra: 0, Ov:2 }\end{array}$} \\
\hline \multirow{17}{*}{$\begin{array}{l}\text { Urbanization } \\
\text { Control } \\
\text { (17) }\end{array}$} & 19 & 3 & 496.76 & 19.87 & $\mathrm{Va}, \mathrm{Un}(2)$ \\
\hline & 20 & 3 & 30.96 & 1.23 & $\mathrm{St}, \mathrm{Ga}, \mathrm{Pa}$ \\
\hline & 26 & 3 & 287.87 & 11.51 & $\mathrm{Ga}(2), \mathrm{Br}$ \\
\hline & 30 & 2 & 134.44 & 5.37 & $\mathrm{Va}, \mathrm{Ga}$ \\
\hline & 37 & 4 & $1,305.70$ & 52.22 & $\mathrm{Va}, \mathrm{Wa}(2), \mathrm{St}$ \\
\hline & 43 & 1 & 100.78 & 4.03 & $\mathrm{St}$ \\
\hline & 44 & 4 & 345.01 & 13.80 & Va, St, Ga, Un \\
\hline & 48 & 3 & $1,742.60$ & 69.70 & $\mathrm{Un}(2), \mathrm{Ga}$ \\
\hline & 49 & 1 & $2,497.42$ & 99.89 & Un \\
\hline & 61 & 4 & $1,031.20$ & 41.24 & $\mathrm{Un}(4)$ \\
\hline & 63 & 2 & 152.89 & 6.11 & $\mathrm{Va}, \mathrm{Ga}$ \\
\hline & 69 & 2 & 236.16 & 9.44 & $\mathrm{Wa}, \mathrm{Pa}$ \\
\hline & 73 & 1 & 413.17 & 16.52 & Un \\
\hline & 86 & 7 & 205.78 & 8.23 & $\begin{array}{l}\mathrm{Va}(2), \mathrm{St}(3), \mathrm{Ga}, \\
\mathrm{Un}\end{array}$ \\
\hline & 87 & 2 & 366.05 & 14.64 & $\mathrm{Un}, \mathrm{St}$ \\
\hline & 88 & 2 & 254.64 & 10.18 & $\mathrm{Va}(2)$ \\
\hline & 101 & 6 & 273.74 & 10.94 & $\mathrm{Va}, \mathrm{Ga}(4), \mathrm{Br}$ \\
\hline \multicolumn{2}{|c|}{ subtotal } & 50 & $9,875.17$ & \multicolumn{2}{|c|}{$\begin{array}{c}\text { Va:10, St: 8, Wa: 3, Ga: } 12, \\
\text { Br:2, Un:13, Pa:2, Ra: 0, Ov: } 0\end{array}$} \\
\hline
\end{tabular}

\footnotetext{
${ }^{1}$ Sample site number. ${ }^{2}$ Number of IGS that are distributed in the sample site. ${ }^{3}$ Amount of IGS area in each sample site. ${ }^{4}$ Percentage of IGSs in the sample sites. ${ }^{6}$ Types of IGSs: Vacant lot (Va), Street verge (St), Water verge (Wa), Gap (Ga), Brownfield (Br), Unimproved land (Un), Parking lot verge $(\mathrm{Pa})$, Railroad verge $(\mathrm{Ra})$, and Overgrown structure $(\mathrm{Ov})$. Shaded rows indicate more than $10 \%$ IGS area in a sample site. The number within the brackets of 'Types of IGSs' indicates the number of spaces of each IGS type.
} 


\subsection{Perception of IGS}

In total, 144 students completed the questionnaire. Gender composition was balanced, with 74 males $(51.4 \%)$ and 70 females (48.6\%) aged 19 to 25 (Table 5). 64 students $(44.4 \%)$ had experience with green volunteer activities such as tree planting, weeding, cleaning, monitoring and observing creatures. Their average number of times participated was 5.164 (maximum value: 21). There were 109 students $(75.7 \%)$ who had experience in gardening activities such as growing and managing plants in the garden, veranda, and allotment. While 44 respondents (30.6\%) perceived surrounding green spaces as abundant, 65 respondents $(45.2 \%)$ indicated a lack of green spaces in their surrounding area. Respondents who were exposed to green space in their living spaces, including detached houses and multiplex housing, were the majority, $85(69.0 \%)$. Approximately half of the respondents were using green spaces less than three times a year or were not using them at all.

Table 5. Descriptive Statistics of Respondents' Composition

\begin{tabular}{c|ccc}
\hline & Composition & $\mathrm{n}=144$ & $(\%)$ \\
\hline \multirow{2}{*}{ Sex } & Male & 74 & 51.4 \\
& Female & 70 & 48.6 \\
\hline Age & $19 \sim 25$ & 144 & 100 \\
\hline Green & No & 80 & 55.6 \\
volunteer & Yes & 64 & 44.4 \\
experience & Average participation frequency: 5.164 & \\
& (minimum value =1, maximum value $=21, \mathrm{SD}=4.8826)$ \\
\hline \multirow{2}{*}{ Gardening } & Never & 35 & 24.3 \\
experience & At least once in the past, but not currently & 65 & 45.1 \\
& Actively engaged & 44 & 30.6 \\
\hline \multirow{3}{*}{$\begin{array}{c}\text { Opinion of the } \\
\text { abundance of }\end{array}$} & Strong lack of GS & 4 & 2.8 \\
surrounding & Lack of GS & 61 & 42.4 \\
green space & Adequate GS & 35 & 24.3 \\
& Abundant GS & 38 & 26.4 \\
& Highly abundant GS & 6 & 4.2 \\
\hline Type of & Detached house with garden & 51 & 35.4 \\
housing & Detached house without garden & 16 & 11.1 \\
& Multiplex housing with shared green spaces & 34 & 23.6 \\
& Multiplex housing without shared green spaces & 43 & 29.9 \\
\hline Frequency of & Never & 44 & 30.6 \\
use of green & $1 \sim 3$ times a year & 26 & 18.8 \\
space & $1 \sim 3$ times a month & 32 & 22.2 \\
& $1 \sim 3$ times a week & 27 & 18.8 \\
& everyday & 14 & 9.7 \\
\hline & & &
\end{tabular}

We asked questions about overall perception of IGS merits to understand whether participants recognize the possibilities of IGS. Questions were organized in five categories with eight questions using 5-level Likert scales (strongly disagree $=1$, disagree $=2$, neither disagree nor agree $=3$, agree $=4$, strongly agree $=5$ ). Responses to each question had a mean value of 3.5 for all subjects (Table 6), indicating an overall appreciation for the merits of IGS. They were highly aware of the ecological value that IGS may play as a role as a habitat for animals and plants. 


\begin{tabular}{lcc} 
Table 6. The mean and standard deviation of the IGS merits perceived by students (N=144) \\
\hline \multicolumn{1}{c}{ Variable } & $\mathrm{M}$ & $\mathrm{SD}$ \\
\hline Urban aesthetic & 4.01 & 1.058 \\
\hline It makes the urban landscape beautiful. & 4.09 & .892 \\
It can make you feel nature in the urban area. & 3.78 & .904 \\
\hline Location & & \\
\hline It is located near. & 3.50 & 1.024 \\
\hline Activities & 4.02 & .832 \\
\hline It can be used for free activities. & & \\
It can be a playground for children. & 4.17 & .796 \\
\hline Ecology & & \\
\hline It can be a habitat for living things. & 3.58 & .927 \\
\hline Health & 4.04 & .835 \\
\hline It is helpful in suppressing soil dust. & \\
IGS plants can play a role in air purification. &
\end{tabular}

We further asked whether the respondents were aware of IGS in their surroundings (Figure 5). More than 50\% of the respondents stated that they knew IGSs in their environment for most types of IGS, except for 'water verges', 'brownfields', and 'unimproved lands'. The highest value was 'street verges' with $81.9 \%(\mathrm{n}=118)$ and the lowest one was 'brownfields' with $27.1 \%(n=39)$.

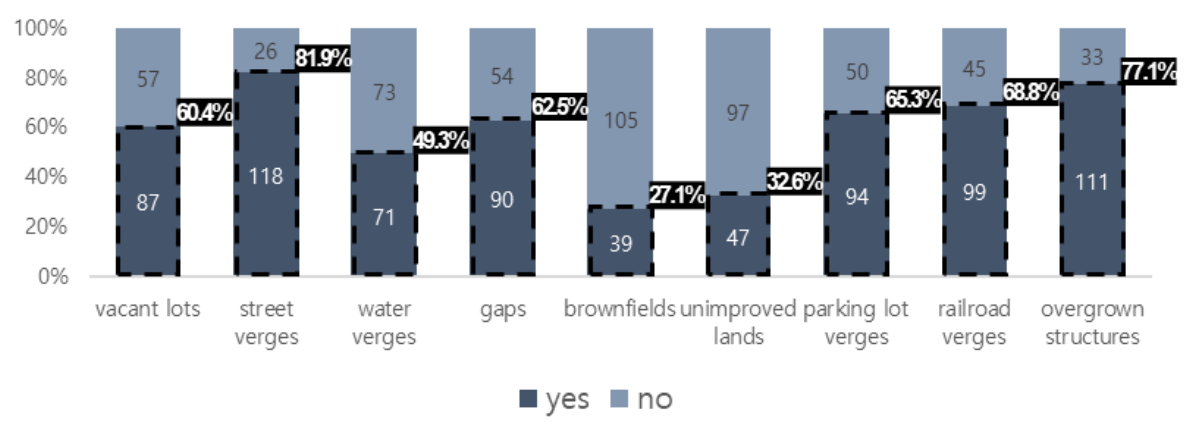

Figure 5. Perceived presence or absence of IGS in the respondent' surroundings $(n=144)$

Next, we asked respondents who are aware that IGS is in the vicinity of their living environment how many discrete IGSs they think exist close by. The mean number of IGSs perceived to exist by the respondents ranged from 1.76 for 'unimproved lands' to 5.08 for 'street verges' (Table 7). Several respondents answered "many", "so many", and "cannot count the number" as a text form, not the number, in the blank of the question. These were excluded in calculating the results, leading to a low response rate for 'street verges' even though it ranked highest for mean value.

Table 7. The number of IGSs known to respondents

\begin{tabular}{c|c|c|c|c|c|c}
\hline IGSs & $\mathrm{N}$ & $(\%)^{*}$ & Mean & Min. value & Max. value & SD \\
\hline Vacant lots & $84(87)$ & 96.5 & 2.73 & 1 & 20 & 2.897 \\
\hline Street verges & $102(118)$ & 86.4 & $\mathbf{5 . 0 8}$ & 1 & 31 & 5.764 \\
\hline Water verges & $66(71)$ & 92.9 & 2.24 & 1 & 20 & 2.481 \\
\hline Gaps & $79(90)$ & 87.7 & 4.19 & 1 & 20 & 4.324 \\
\hline Brownfields & $35(39)$ & 89.7 & 2.29 & 1 & 20 & 3.195 \\
\hline Unimproved lands & $45(47)$ & 95.7 & 1.76 & 1 & 10 & 1.525 \\
\hline Parking lot verges & $83(94)$ & 88.2 & 3.14 & 1 & 20 & 3.250 \\
\hline Railroad verges & $88(99)$ & 88.8 & 2.36 & 1 & 15 & 2.345 \\
\hline
\end{tabular}




\begin{tabular}{c|c|c|c|c|c|c}
\hline IGSs & $\mathrm{N}$ & $(\%)^{*}$ & Mean & Min. value & Max. value & SD \\
\hline Overgrown structures & $97(111)$ & 87.3 & 3.29 & 1 & 20 & 3.406 \\
\hline
\end{tabular}

*Among the respondents who answered 'yes', the percentage of the people who filled in the number of IGSs.

To understand the participants' view of different IGS types, we asked them whether they think IGS could be a form of urban green space using 5level Likert scales. We aggregated answers into three levels: 'disagree including strongly disagree', 'neither disagree nor agree', and 'agree including strongly agree'. Five IGS types were perceived as a possible form of urban green space by the majority of respondents: 'street verges $(75.0 \%)$ ', 'unimproved lands $(71.5 \%)$ ', 'water verges $(70.8 \%)$ ', 'overgrown structures (67.4\%)', and 'vacant lots (56.9\%)' (Figure 6).

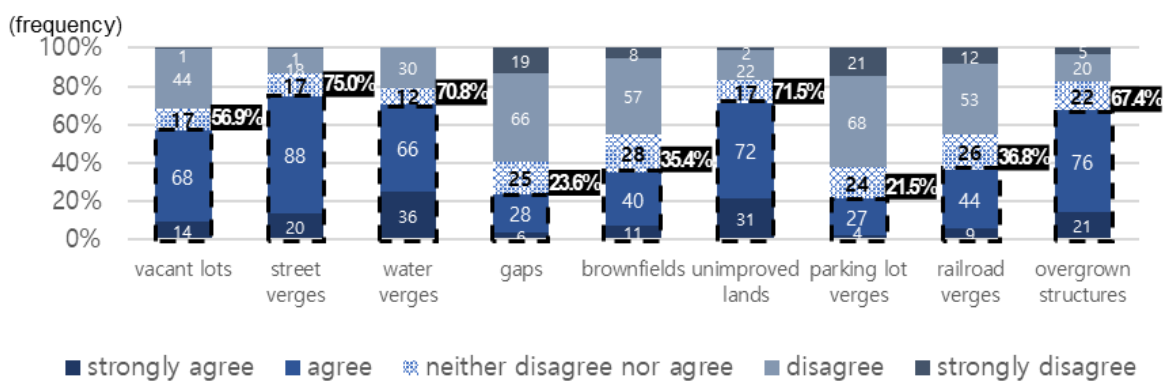

Figure 6. Perception as an urban green space for different types of IGS

\section{DISCUSSION AND CONCLUSION}

This study contributed to our understanding of informal green space as supplementary green space in the urban area. In particular, we discuss our findings below with a focus on (1) the typology of IGS, (2) perception of IGS, and (3) implications for urban planning, before we conclude with limitations and directions for future research.

\subsection{Expanding typologies of IGS: What other types of non-standardized and unsystematised green spaces are there?}

We managed to identify nine types of IGS: vacant lots, street verges, water verges, gaps, brownfields, unimproved lands, parking lot verges, railroad verges, and overgrown structures. In particular, the addition of the new types of IGS 'unimproved lands' and 'parking lot verges' to the typology proposed by Rupprecht, Christoph D D and Byrne (2014a) represents an important contribution to the emerging field of IGS research and shows that this field is still in its early stages, with more major fundamental contributions to be expected. The reason why we were able to identify other types of IGS in comparison to prior research despite a similar number of sample sites may be attributed to the more diverse land use patterns in Ichikawa City. Prior research also focused on the urban core, whereas the improved study design employed here distributed sample sites across a wider gradient of urbanization. As shown in Table 4, 'unimproved lands' were more frequently found in urbanization control districts than in other areas. 'Parking lot verges' could be considered as 'vacant lots' 
because of their structural characteristics, but in terms of their placement in a space used for a particular purpose, the properties of the space may differ from 'vacant lots' and thus merit distinction as a separate IGS type. IGSs we found in the study site frequently showed characteristics of wasteland covered with spontaneous vegetation without human control for an extended period of time (Muratet et al., 2007; Mathey \& Rink, 2010). IGS was located in the close living environment and was widely distributed, making it easy to find for residents. Since the types of 'brownfields' and 'unimproved lands' have specific locational characteristics, these types are often located in the outskirts of cities, industrial districts, and restricted development districts rather than in densely populated residential or commercial areas. Therefore, there may be a difference in IGS accessibility between respondents who reside in or around a certain land use pattern and those who do not. If 'brownfield' and 'unimproved lands' are excluded when considering locational characteristics, roughly more than half of the respondents were aware that IGS was distributed throughout their living environments. Considering that all study sites were distributed at uniform intervals for the sampling strategy, the IGS proportion of all surveyed land (6.36\%) can be extrapolated (Rupprecht, Christoph D D \& Byrne, 2014a) for the whole of Northern Ichikawa - a significant land use type and a valuable part of urban nature, which emphasizes the importance of understanding how it is perceived.

\subsection{How do people perceive IGS?}

Prior research demonstrates that urban nature with spontaneous plants can be suitable for environmental education, recreation, and nature experiences (Mathey \& Rink, 2010; Rupprecht, Christoph D D et al., 2015). As such it comes as no surprise that our respondents, who had experience studying green space, had a mostly positive perception regarding IGS in general. This finding is nevertheless an important contribution to our understanding of IGS, as the undergraduate students enrolled in landscape and agricultural science programs are likely to have a strong influence on urban green space policy as they take up professional careers in the sector. They felt that IGS can play an essential role in urban areas for human wellbeing, but there the perception differed between each IGS type. This result supports findings from previous research (Rupprecht, Christoph D D et al., 2015). When the respondents considered IGS as a whole for the first time, they tended to refer to IGS as equivalent to a part of nature. However, after examining IGS more closely by looking at each type, their opinion changed depending on the condition of maintenance or the individual experience of the green space. This reflects problems identified by prior research, where wastelands with semi-natural vegetation were found to contribute to urban ecosystems, but public perception was influenced by abandonment, emptiness, and hazards (Millard, 2004). This is likely due to the public perception towards green space being shaped by horticultural landscapes and notions of what constitutes 'right' and 'wrong' nature (Jorgensen \& Tylecote, 2007; Del Tredici, 2010; Kowarik \& Korner, 2014). However, the results of our survey also provide insights into how IGS, and specific IGS types, may be able to become supplementary green space in cities like Ichikawa where UGS is scarce. 


\subsection{Implications for planning: Could IGS be considered as supplementary green space for Ichikawa City and beyond?}

The findings of our IGS land use and perception surveys have clear implications for urban green space planning. 'Street verges' were identified by our respondents as IGS that could serve as supplementary green space. Respondents perceived 'street verges' as most common in the vicinity of their living environment, and the average number perceived was also the highest among all IGS types. Moreover, respondents were most likely to see it as a green space. 'Gaps' were also strongly perceived as closely located IGS with an average of 4.19 spaces, but their perception as green space was the lowest together with 'parking lot verges'. This means to integrate IGS into green planning, urban planners need to know not only how much IGS is available in their city, but what types there are and how they are perceived by their residents. Some of these types may also exhibit special characteristics that need to be taken into account by planning interventions. For example, unlike IGS in the form of horizontal space, 'overgrown structures' are vertical spaces that may appeal in different ways from traditional green spaces.

The wide distribution and its role as an everyday part of urban nature have further implications for planning, and are crucial in answering the question whether IGS can serve as supplementary green space. Diverse research has increasingly addressed the availabilities of IGS including wasteland and urban wild space. Although not all residents value it, the perception of the general public in prior research points towards the potential and arguably constitutes a mandate for creating systems to better utilize IGS (Hofmann et al., 2012; Rupprecht, Christoph D D \& Byrne, 2014a). One of the most important characteristics of IGS is its accessibility in the living environment of the residents (Figure 5 and Table 6), and that participants perceived it as a green space. Municipalities faced with the double burden of meeting the residents' expectations for quality of life and improving it by creating green spaces amidst financial shortages in tax income due to demographic decline (Rupprecht, Christoph D.D., 2017) can aim for synergistic effects in considering IGS as supplementary green space. Such a strategy might entail using IGS as a temporary green space while sidestepping the financial hurdle of creating new green spaces by acquiring land. The distribution of IGS throughout cities would contribute toward a densely knit and highly connected green infrastructure network system.

However, hurdles to using IGS remain. Most IGS is privately owned even though it has not received any attention over an extended period of time. A detailed discussion exceeds the scope of this paper, but the issue has been thoroughly discussed in prior research (Rupprecht, Christoph D D et al., 2015; Rupprecht, Christoph D.D., 2017). These issues are further complicated by the discourse around the questions of whether IGS will contribute to urban ecology by retaining the urban wildness composed of spontaneous plants with no human activity (Kowarik \& Korner, 2014), or whether recreation might be prioritized over conservation through use as a minimum human intervention recreational space.

\subsection{Limitations and directions for future research}

This study has a number of limitations. The area surveyed was limited to Northern Ichikawa, so more work is needed to better understand IGS in 
various contexts. Furthermore, this exploratory study reported results of the land use survey, but an advanced analysis of factors that potentially influence spatial IGS distribution patterns exceeds the scope of this paper. Statistical and GIS-based analysis of such patterns in Ichikawa City and other places would likely contribute to deepening our understanding of the mechanisms.

We conducted a preliminary survey about the IGS perception of students who were familiar with UGS and were able to identify the availabilities of IGS as a part of supplementary green space. However, their responses do not allow generalization to the general population of Ichikawa. Therefore, a follow-up survey of residents' perception of IGS is warranted to compare and see whether residents also see IGS as closely connected with their living environment as our student respondents. Such a survey could be combined with a GIS analysis of available IGS in Ichikawa to analyse accessibility. Since IGS is often within walking distance as shown by previous research (Rupprecht, Christoph D D et al., 2015) and further supported by the distance between sample sites in this study $(500 \mathrm{~m})$, it may be easier to access as no money for transport or extended physical effort is necessary. Considering the locational characteristics of IGS, this may benefit specific population groups such as women, children and adolescents, older adults, and deprived subpopulations and minority groups (WHO Regional Office for Europe, 2016).

\section{ACKNOWLEDGMENTS}

We thank the participants of this study for their support, and the editors and reviewers for their helpful comments. This research was supported by the FEAST Project (No. 14200116), Research Institute for Humanity and Nature (RIHN), and supported by JSPS KAKENHI Grant Numbers JP17K08179, JP17K15407.

\section{REFERENCES}

Barbosa, O., Tratalos, J. A., Armsworth, P. R., Davies, R. G., Fuller, R. A., Johnson, P., \& Gaston, K. J. (2007). "Who Benefits from Access to Green Space? A Case Study from Sheffield, Uk". Landscape and Urban Planning, 83(2-3), 187-195. doi: https://doi.org/10.1016/j.landurbplan.2007.04.004.

Benedict, M. A., \& McMahon, E. T. (2002). "Green Infrastructure: Smart Conservation for the 21st Century". Renewable Resources Journal, 20(3), 12-17.

Bertram, C., \& Rehdanz, K. (2015). "The Role of Urban Green Space for Human WellBeing". Ecological Economics, 120, 139-152. doi: https://doi.org/10.1016/j.ecolecon.2015.10.013.

Cohen-Shacham, E., Walters, G., Janzen, C., \& Maginnis, S. (Eds.). (2016). Nature-Based Solutions to Address Global Societal Challenges. Gland, Switzerland: Union for Conservation of Nature (IUCN).

Del Tredici, P. (2010). "Spontaneous Urban Vegetation: Reflections of Change in a Globalized World". Nature + Culture, 5(3), 299-315. doi: https://doi.org/10.3167/nc.2010.050305.

Edensor, T. (2005). "The Ghosts of Industrial Ruins: Ordering and Disordering Memory in Excessive Space". Environment and Planning D: Society and Space, 23(6), 829-849. doi: https://doi.org/10.1068/d58j.

Hirzel, A. H., \& Guisan, A. (2002). "Which Is the Optimal Sampling Strategy for Habitat Suitability Modelling". Ecological modelling, 157(2-3), 331-341. doi: https://doi.org/10.1016/S0304-3800(02)00203-X. 
Hofmann, M., Westermann, J. R., Kowarik, I., \& Van der Meer, E. (2012). "Perceptions of Parks and Urban Derelict Land by Landscape Planners and Residents". Urban Forestry and Urban Greening, 11(2), 303-312. doi: https://doi.org/10.1016/j.ufug.2012.04.001.

Ichikawa City Urban Planning Division. (2004). "Ichikawa Green Master Plan 2004". Ichikawa, Japan: Ichikawa City Urban Planning Division.

Ichikawa City Urban Planning Division. (2013). "Ichikawa Urban Master Plan 2013". Ichikawa, Japan: Ichikawa City Urban Planning Division.

Ichikawa City Urban Planning Division. (2017). "Urban Infra of Ichikawa Based on Data 2017". Ichikawa, Japan: Ichikawa City Urban Planning Division.

Jorgensen, A., \& Tylecote, M. (2007). "Ambivalent Landscapes-Wilderness in the Urban Interstices". Landscape Research, 32(4), 443-462. doi: https://doi.org/10.1080/01426390701449802.

Kowarik, I., \& Korner, S. (2014). "Wild Urban Woodlands". Igarss 2014, 1-5. doi: 10.1007/s13398-014-0173-7.2.

Martin, C. A., Warren, P. S., \& Kinzig, A. P. (2004). "Neighborhood Socioeconomic Status Is a Useful Predictor of Perennial Landscape Vegetation in Residential Neighborhoods and Embedded Small Parks of Phoenix, Az". Landscape and urban planning, 69(4), 355-368. doi: https://doi.org/10.1016/j.landurbplan.2003.10.034.

Mathey, J., \& Rink, D. (2010). "Urban Wastelands - a Chance for Biodiversity in Cities? Ecological Aspects, Social Perceptions and Acceptance of Wilderness by Residents, in Urban Biodiversity and Design". In Müller, N., Werner, P., \& Kelcey, J. G. (Eds.), Urban Biodiversity and Design: John Wiley \& Sons. doi: https://onlinelibrary.wiley.com/doi/abs/10.1002/9781444318654.ch21.

Mensah, C. A. (2014). "Destruction of Urban Green Spaces: A Problem Beyond Urbanization in Kumasi City (Ghana)". American Journal of Environmental Protection, 3(1), 1-9. doi: https://doi.org/10.11648/j.ajep.20140301.11.

Millard, A. (2004). "Indigenous and Spontaneous Vegetation: Their Relationship to Urban Development in the City of Leeds, Uk". Urban Forestry and Urban Greening, 3(1), 39-47. doi: https://doi.org/10.1016/j.ufug.2004.04.004.

Muratet, A., Machon, N., Jiguet, F., Moret, J., \& Porcher, E. (2007). "The Role of Urban Structures in the Distribution of Wasteland Flora in the Greater Paris Area, France". Ecosystems, 10, 661-671. doi: https://doi.org/10.1007/s10021-007-9047-6.

Rupprecht, C. D. D. (2017). "Informal Urban Green Space: Residents' Perception, Use, and Management Preferences across Four Major Japanese Shrinking Cities". Land, 6(3), 59. doi: https://doi.org/10.3390/land6030059.

Rupprecht, C. D. D., \& Byrne, J. A. (2014a). "Informal Urban Green-Space: Comparison of Quantity and Characteristics in Brisbane, Australia and Sapporo, Japan". PLoS ONE, 9(6), e99784. doi: https://doi.org/10.1371/journal.pone.0099784.

Rupprecht, C. D. D., \& Byrne, J. A. (2014b). "Informal Urban Greenspace: A Typology and Trilingual Systematic Review of Its Role for Urban Residents and Trends in the Literature". Urban Forestry and Urban Greening, 13(4), 597-611. doi: https://doi.org/10.1016/j.ufug.2014.09.002.

Rupprecht, C. D. D., Byrne, J. A., Ueda, H., \& Lo, A. Y. (2015). "'It's Real, Not Fake Like a Park': Residents' Perception and Use of Informal Urban Green-Space in Brisbane, Australia and Sapporo, Japan". Landscape and Urban Planning, 143, 205-218. doi: https://doi.org/10.1016/j.landurbplan.2015.07.003.

Shoard, M. (2000). "Edgelands of Promise". Landscapes, 1(2), 74-93. doi: https://doi.org/10.1179/lan.2000.1.2.74.

Speer, J. (2015). "Urban Interstices: The Aesthetics and the Politics of the in-Between". Emotion, Space and Society (Vol. 14, pp. 43-44). doi: 10.1016/j.emospa.2015.01.001.

United Nations, Department of Economic and Social Affairs, Population Division. (2015). "World Urbanization Prospects - the 2014 Revision". (ST/ESA/SER.A/366), Retrieved from https://population.un.org/wup/Publications/Files/WUP2014-Report.pdf.

WHO Regional Office for Europe. (2016). "Urban Green Spaces and Health: A Review of the Evidence". Copenhagen: World Health Organization (WHO) Regional Office for Europe. Retrieved from http://www.euro.who.int/_data/assets/pdf_file/0005/321971/Urban-greenspaces-and-health-review-evidence.pdf?ua=1.

Wright Wendel, H. E., Zarger, R. K., \& Mihelcic, J. R. (2012). "Accessibility and Usability: Green Space Preferences, Perceptions, and Barriers in a Rapidly Urbanizing City in Latin America". Landscape and Urban Planning, 107(3), 272-282. doi: https://doi.org/10.1016/j.landurbplan.2012.06.003. 